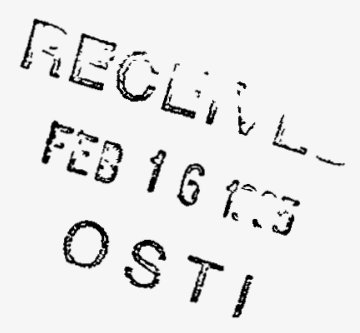

\title{
AFFORDABLE HOUSING: REDUCING THE ENERGY COST BURDEN
}
A. D. Lee
R. I. Chin
C. L. Marden

Prepared for the U.S. Department of Energy under Contract DE-AC06-76RLO 1830

Pacific Northwest Laboratory

Richland, Washington 



\section{DISCLAIMER}

This report was prepared as an account of work sponsored by an agency of the United States Government. Neither the United States Government nor any agency thereof, nor any of their employees, make any warranty, express or implied, or assumes any legal liability or responsibility for the accuracy, completeness, or usefulness of any information, apparatus, product, or process disclosed, or represents that its use would not infringe privately owned rights. Reference herein to any specific commercial product, process, or service by trade name, trademark, manufacturer, or otherwise does not necessarily constitute or imply its endorsement, recommendation, or favoring by the United States Government or any agency thereof. The views and opinions of authors expressed herein do not necessarily state or reflect those of the United States Government or any agency thereof. 


\section{DISCLAIMER}

Portions of this document may be illegible in electronic image products. Images are produced from the best available original document. 


\section{SUMMARY}

Residential energy expenditures are a key determinant of housing affordability, particularly for lower income households. For years, federal, state and local governments and agencies have sought to defray energy expenses and increase residential energy efficiency for low income households through legislative and regulatory actions and programs. Nevertheless, household energy costs continue to place a major burden on lower income families. This issue paper was written to help formulate national energy policy by providing the United States Department of Energy's (DOE's) Office of Energy Efficiency and Renewable Energy (EE) with information to help define the affordable housing issue; identify major drivers, key factors, and primary stakeholders shaping the affordable housing issue; and review how responding to this issue may impact EE's goals and objectives and influence the strategic direction of the office. Typically, housing affordability is an issue associated with lower income households. This issue paper adopts this perspective, but it is important to note that reducing energy utility costs can make "better" housing affordable to any household regardless of income.

As energy efficiency is improved throughout all sectors of the economy, special consideration must be given to low income households. Of all households, low income households are burdened the most by residential energy costs; their residences often are the least energy-efficient and have the greatest potential for efficiency improvements, but the occupants have the fewest resources to dedicate to conservation measures.

This paper begins with a definition of "affordability" as it pertains to total housing costs. Table S.1 summarizes several key statistics related to housing affordability and energy use by lower income households.

Lower income households dedicate much more of their income to housing than other households: $54 \%$ of low income households and $69 \%$ of very low income households are over-burdened or "costburdened" by total housing costs, and the burden is much higher for occupants of rental than owneroccupied housing. ${ }^{\left({ }^{\circ}\right)}$ Rental housing is far more common among lower income households than other households: over half the very low income households are renters. One fifth of low income households occupy public or subsidized housing, which helps them afford housing, but excessive energy use in these units places a direct cost on society at large, as well as on the occupants. ${ }^{(b)}$

Energy costs are less for low income households than other households, but they are a much larger share of housing costs for lower income families than for other families. In addition, lower income households probably reduce their comfort and energy services to keep utility bills down. Household energy bills make up $21 \%$ and $26 \%$ of housing costs for low income and very low income households, respectively, but only $13 \%$ of housing costs for all other households. Very low income households spend $12 \%$ of their income on household energy costs, compared with $2 \%$ spent by households with

(a) HUD defines "cost-burdened" differently for owned and rented housing: For owners, those spending more than $40 \%$ of their income on housing costs are cost-burdened and for renters the comparable figure is $30 \%$ (Prindle 1988).

(b) The authors calculated these statistics based on data from the U.S. Department of Housing and Urban Development (HUD 1993.) 
Table S.1 Summary Statistics Related to Housing Affordability

\begin{tabular}{|c|c|c|c|}
\hline Characteristic & $\begin{array}{l}\text { Very low income } \\
\text { households }\end{array}$ & $\begin{array}{l}\text { Low income house- } \\
\text { holds }\end{array}$ & Other households \\
\hline Number of households & $23,710,000$ & $39,926,000$ & $53,221,000$ \\
\hline Median annual income & $\$ 7,990$ & $\$ 15,340$ & $\$ 61,982$ \\
\hline Avg. age of dwelling & 32 years & 30 years & 21 years \\
\hline Avg. size of dwelling, sq. ft. & 1,200 & 1,310 & 1,880 \\
\hline Share of households renting & $55 \%$ & $48 \%$ & $23 \%$ \\
\hline $\begin{array}{l}\text { Housing type, owned } \\
\text { homes: } \\
\text { Single-family } \\
\text { Multi-family } \\
\text { Mobile home }\end{array}$ & $\begin{array}{l}80 \% \\
6 \% \\
15 \%\end{array}$ & $\begin{array}{l}81 \% \\
6 \% \\
13 \% \\
\end{array}$ & $\begin{array}{l}91 \% \\
5 \% \\
4 \%\end{array}$ \\
\hline $\begin{array}{l}\text { Housing type, rented homes: } \\
\text { Single-family } \\
\text { Multi-family } \\
\text { Mobile home }\end{array}$ & $\begin{array}{l}30 \% \\
66 \% \\
4 \%\end{array}$ & $\begin{array}{l}31 \% \\
65 \% \\
4 \%\end{array}$ & $\begin{array}{l}39 \% \\
60 \% \\
2 \%\end{array}$ \\
\hline $\begin{array}{l}\text { Share of income spent on } \\
\text { housing costs }\end{array}$ & $47 \%$ & $35 \%$ & $16 \%$ \\
\hline $\begin{array}{l}\text { Share of households "cost- } \\
\text { Jurdened": } \\
\text { Renters } \\
\text { Owners }\end{array}$ & $\begin{array}{l}81 \% \\
41 \%\end{array}$ & $\begin{array}{l}64 \% \\
29 \%\end{array}$ & $\begin{array}{l}13 \% \\
14 \%\end{array}$ \\
\hline $\begin{array}{l}\text { Share of households in pub- } \\
\text { lic or subsidized housing }\end{array}$ & $29 \%$ & $20 \%$ & $5 \%$ \\
\hline $\begin{array}{l}\text { Annual household energy } \\
\text { use: } \\
10^{3} \mathrm{Btu} / \mathrm{sq} . \mathrm{ft} . \\
\$ / \mathrm{sq} . \mathrm{ft} \text {. }\end{array}$ & $\begin{array}{l}61 \\
0.71\end{array}$ & $\begin{array}{l}57 \\
0.69\end{array}$ & $\begin{array}{l}50 \\
0.62\end{array}$ \\
\hline $\begin{array}{l}\text { Household energy expendi- } \\
\text { tures: } \\
\text { Annual amount } \\
\text { Share of income }\end{array}$ & $\begin{array}{l}\$ 938 \\
12 \%\end{array}$ & $\begin{array}{l}\$ 1010 \\
7 \%\end{array}$ & $\begin{array}{l}\$ 1459 \\
2 \%\end{array}$ \\
\hline \multicolumn{4}{|c|}{$\begin{array}{l}\text { Note: "Very low income" households include all those with incomes below } 50 \% \text { of the median; "lov } \\
\text { income" households include all those with incomes below } 80 \% \text { of the median; "other" households } \\
\text { are those with incomes above } 80 \% \text { of the median (National Affordable Housing Act 1990.) } \\
\text { (a) The authors calculated these statistics and those above them based on data from the U.S. } \\
\text { Department of Housing and Urban Development (HUD 1993). } \\
\text { (b) Statistics in last two rows are derived from Energy Information Administration (EIA 1993a). }\end{array}$} \\
\hline
\end{tabular}


incomes greater than the low income level. In addition, while low income households occupy smaller units than other households, they pay about $11 \%$ more per square foot for household energy. ${ }^{(a)}$

These statistics suggest that the lower income housing affordability issue is two-pronged: 1) lower income household buildings and appliances are less efficient and 2) the relative economic impacts of energy use are larger. Factors affecting energy consumption levels include the type, size, and age of dwellings; the dwelling location; climate; amount of insulation; the efficiency of heating/cooling systems, water heaters, and appliances; and occupant knowledge and behavior.

Lower income households live in buildings that are about 10 years older, on the average, than other households. Older buildings tend to be less efficient than buildings built under more recent energy codes. Lower income households are more than twice as likely to rent their homes as other households. Rental housing poses special problems for increasing energy efficiency because the occupant and owner are different individuals. Lower income households are three times as likely to live in mobile homes. Mobile homes have lagged behind site-built housing in terms of energy efficiency improvements.

For all households, more energy is used for space heating than any other end-use. On the average, however, more is spent on miscellaneous appliance energy use $(35 \%)$ than space heating $(31 \%)$ because of the higher cost of electricity relative to gas and oil for heating (EIA 1993a). Expenditures by low income households follow a similar pattern by end-use; space heating costs, however, are slightly more than energy costs for miscellaneous appliances. Adding in refrigerators, energy costs for all appliances are nearly $43 \%$ of the total energy costs of low income households. Energy use and expenditure patterns vary by geographic location. Monthly energy expenditures by low income households are least in the West, $\$ 64$, and most in the Northeast, $\$ 103$.

Numerous federal, state and local government bodies attempt to reduce residential energy costs through building and appliance efficiency standards, direct subsidies, weatherization projects, and other programs. This paper describes some of the most influential and effective legislation, policies and programs, but a thorough examination of all activities is beyond the scope of this paper.

Utilities have become a significant force in improving residential energy efficiency. Motivated by pressure to decrease emissions and the desire to avoid expensive increases in capacity, utilities currently sponsor over 700 individual programs aimed at improving the efficiency of residences or specific household appliances. Certain programs are directly targeted toward low income households, while others provide income-based grants or subsidies for conservation measures.

Limited profit potential discourages many builders from constructing small, modestly priced housing. This has contributed to the growth of non-profit residential construction organizations that build inexpensive homes for low income households.

An examination of the low income housing stock, household characteristics and energy expenditures, and current energy conservation and assistance activities suggests. several possibilities for further reduction of low income household energy consumption and costs. Future efforts by DOE to contribute

(a) The authors calculated these statistics based on data from HUD (1993). 
to housing affordability improvements can rely on three key strategies that are consistent with DOE's strategic planning activities: 1) technology advancement efforts, 2) market mobilization, and 3) DOE organizational management strategies.

The highest priority options suggested for addressing the affordable housing issue are summarized below:

- Increase research, development, and commercialization emphasis on low-cost, no-cost energyefficiency and renewables technologies: In the past, EE has emphasized technological advancement over cost reductions, but increased research on significant cost reductions in efficiency and renewable energy technologies could improve housing affordability.

- Develop improved technologies to upgrade the energy efficiency of existing housing and appliances: Because a disproportionate share of lower income households resides in older homes, weatherization technologies are essential in efforts to increase housing affordability. Low-cost technologies that can be installed or steps that can be taken in existing housing may be very cost-effective.

- Develop collaborative programs with industry, utilities, and others to promote low-cost efficiency and renewable technologies.

- Accelerate adoption of building and appliance efficiency standards and extend standards to additional appliances and equipment.

- Design and implement market transformation programs emphasizing lower income households: Market transformation programs aim to permanently increase the efficiency of selected products or systems, usually through short-term funding or incentives. Such programs should be conducted in a way so that they increase the efficiency of a wide line of products, not just topof-the-line products.

- Improve lending terms for lower income households to purchase energy-efficient housing: DOE could collaborate with HUD and lenders to design and implement programs that include lower interest rates, reduced down-payment requirements, extended loan terms, and more flexible loan qualification criteria for energy-efficient homes.

- Implement programs to promote lower income housing based on sustainable design and construction principles: DOE could provide the analysis needed to increase the sustainability of lower income housing. The consumption of all fuels and other resources, such as water, should be included in the analysis.

- Incorporate significant efficiency improvements into lower income housing during major rehabilitation: DOE could work with HUD, local agencies, utilities and others to incorporate such improvements during lower income housing rehabilitation projects.

- Increase the importance of cost reductions in EE's organizational objectives.

- Adopt an organizational goal of promoting equitable, affordable housing. 
- Continue to shift emphasis from subsidizing energy bills to making permanent efficiency improvements: Housing and energy programs that subsidize energy expenditures provide no incentive to make efficiency improvements that will have long-term benefits, reducing the need for continuing subsidies. Shifting subsidies to investments in energy efficiency can have significant public benefits. 


\section{ACKNOWLEDGMENTS}

We would like to thank the other members of the issue team that was charged with preparing this paper for the U.S. Department of Energy (DOE): Dick Jones, U.S. DOE; Jerome La Montagne, Brookhaven National Laboratory; and Chuck Clinton, Energy Office of Washington, D.C. We would also like to thank several reviewers who provided feedback on the draft paper including the following: Susan Anderson and Laura O'Keefe, Portland, Oregon, Energy Office; Greg Reamy, DOE's Office of Technical and Financial Assistance; Renz Jennings, Arizona Corporation Commission; Kathy Kreiter, Washington State Energy Office; Bion Howard, The Aliance to Save Energy; Scott Bernstein, Center for Neighborhood Technology, Chicago; Alan Meier, Lawrence Berkeley Laboratory; and Robert Groberg, U.S. Department of Housing and Urban Development. The authors also appreciate the support of Bruce Hedman and Lisa Stevenson at PNL whose assistance was critical in completing this work as a part of a larger study. 


\section{TABLE OF CONTENTS}

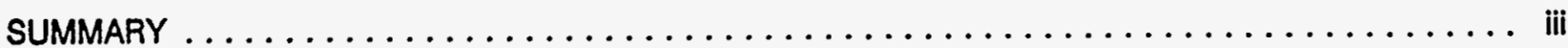

ACKNOWLEDGMENTS $\ldots \ldots \ldots \ldots \ldots \ldots \ldots \ldots \ldots \ldots \ldots \ldots \ldots \ldots \ldots \ldots \ldots$

1.0 BACKGROUND AND INTRODUCTION $\ldots \ldots \ldots \ldots \ldots \ldots \ldots \ldots \ldots \ldots \ldots \ldots \ldots \ldots$

2.0 DEFINITION OF AFFORDABLE HOUSING $\ldots \ldots \ldots \ldots \ldots \ldots \ldots \ldots \ldots \ldots \ldots \ldots \ldots \ldots$

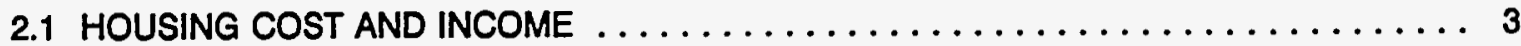

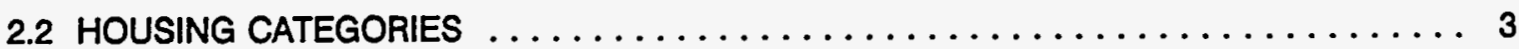

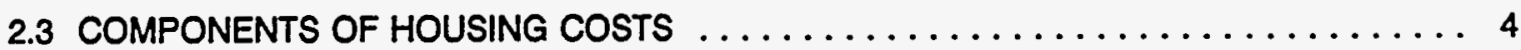

2.4 THE ROLE OF ENERGY CONSUMPTION IN AFFORDABLE HOUSING . . . . . . . 6

3.0 HOUSING AFFORDABILITY FOR LOWER INCOME HOUSEHOLDS $\ldots \ldots \ldots \ldots \ldots \ldots \ldots$

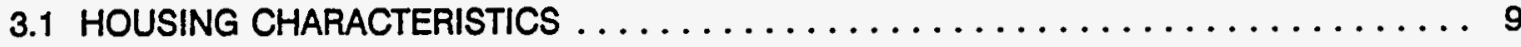

$3.2 \mathrm{KEY}$ STATISTICS RELATED TO AFFORDABILITY $\ldots \ldots \ldots \ldots \ldots \ldots \ldots \ldots \ldots \ldots$

4.0 STAKEHOLDERS AND EXISTING PROGRAMS AND POLICIES FOR ENERGY-EFFICIENT

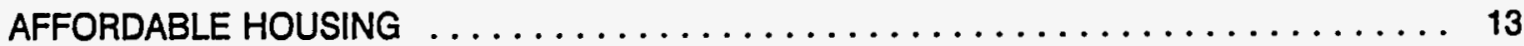

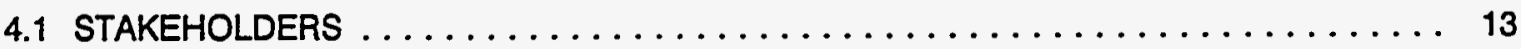

4.2 EXISTING PROGRAMS AND POLICIES AFFECTING ENERGY-EFFICIENT, LOWER INCOME AFFORDABLE HOUSING $\ldots \ldots \ldots \ldots \ldots \ldots \ldots \ldots \ldots \ldots \ldots$

5.0 POTENTIAL OPTIONS FOR OFFICE OF ENERGY EFFICIENCY AND RENEWABLE ENERGY . . 21

5.1 TECHNOLOGY STRATEGY: CONTINUOUS ADVANCEMENT $\ldots \ldots \ldots \ldots \ldots \ldots \ldots 21$

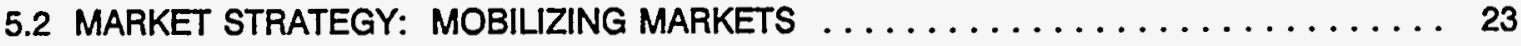

5.3 ORGANIZATIONAL STRATEGY: MANAGING FOR SUCCESS $\ldots \ldots \ldots \ldots \ldots \ldots \ldots 26$

6.0 INFORMATION AND ANALYSIS NEEDS $\ldots \ldots \ldots \ldots \ldots \ldots \ldots \ldots \ldots \ldots \ldots \ldots \ldots$

REFERENCES $\ldots \ldots \ldots \ldots \ldots \ldots \ldots \ldots \ldots \ldots \ldots \ldots \ldots \ldots \ldots \ldots \ldots \ldots \ldots \ldots$

BIBLIOGRAPHY $\ldots \ldots \ldots \ldots \ldots \ldots \ldots \ldots \ldots \ldots \ldots \ldots \ldots \ldots \ldots \ldots \ldots \ldots \ldots \ldots$

APPENDIX: SUPPLEMENTAL HOUSING INFORMATION $\ldots \ldots \ldots \ldots \ldots \ldots \ldots \ldots \ldots \ldots \ldots$ 


\section{FIGURES}

Figure 2.1. Housing Costs and Income Distribution $\ldots \ldots \ldots \ldots \ldots \ldots \ldots \ldots \ldots \ldots$

Figure 2.2. Owner-Occupied Housing Life-Cycle $\ldots \ldots \ldots \ldots \ldots \ldots \ldots \ldots \ldots \ldots \ldots \ldots$

Figure 2.3. Rental Housing Life-Cycle $\ldots \ldots \ldots \ldots \ldots \ldots \ldots \ldots \ldots \ldots \ldots \ldots \ldots \ldots \ldots$

Figure 2.4. Low-Income Energy Expenditures $\ldots \ldots \ldots \ldots \ldots \ldots \ldots \ldots \ldots \ldots \ldots \ldots$

Figure A.1. Types of Owner-Occupied Homes $\ldots \ldots \ldots \ldots \ldots \ldots \ldots \ldots \ldots \ldots \ldots \ldots \ldots \ldots$

Figure A.2. Types of Renter-Occupied Homes $\ldots \ldots \ldots \ldots \ldots \ldots \ldots \ldots \ldots \ldots \ldots \ldots \ldots$

Figure A.3. Housing Costs and Median Income by Region $\ldots \ldots \ldots \ldots \ldots \ldots \ldots \ldots \ldots$

Figure A.4. End-Use Energy Consumption Per U.S. Household by Census Region (EIA 1993b) . . . A.3

\section{TABLES}

Table S.1 Summary Statistics Related to Housing Affordability $\ldots \ldots \ldots \ldots \ldots \ldots \ldots$ iv

Table 3.1. Percentage of Homes Occupied by Low Income Households . . . . . . . . . 10

Table 3.2. Comparisons by Income Group $\ldots \ldots \ldots \ldots \ldots \ldots \ldots \ldots \ldots \ldots \ldots \ldots$

Table 3.3 Differences Across Census Regions for Low Income Households . . . . . . . . . 12

Table 4.1 Stakeholders in the Owner- and Renter-Occupied Housing Market $\ldots \ldots \ldots \ldots$

Table A.1 Summary of Housing Distributions $\ldots \ldots \ldots \ldots \ldots \ldots \ldots \ldots \ldots \ldots \ldots \ldots \ldots \ldots \ldots \ldots$ 


\subsection{BACKGROUND AND INTRODUCTION}

Federal housing policy objectives include increasing the "supply of decent housing that is affordable to low income and moderate income families..." as stated in the Cranston-Gonzalez National Affordable Housing Act of 1990. The act recognizes the importance of household energy use in determining affordability; at least nine sections explicitly require actions or programs involving residential energy consumption and efficiency improvements. This act and others provide the impetus for the U.S. Department of Energy (DOE) and other agency activities to increase housing affordability through increased energy efficiency and utilization of renewable energy resources.

This issue paper was written by Pacific Northwest Laboratory ${ }^{(0)}$ to provide DOE's Office of Energy Efficiency and Renewable Energy (EE) with information to help define the affordable housing issue; identify major drivers, key factors, and primary stakeholders shaping the affordable housing issue; and review how responding to this issue may impact EE's goals and objectives and influence the strategic direction of the office.

The nation's housing stock consists of 104.6 million housing units; about 1.6 million new units are constructed each year (EIA 1993a; HUD 1993). While the housing supply is large, $31 \%$ of households are considered to be "cost-burdened" according to HUD guidelines. ${ }^{(b)}$ Housing costs of cost-burdened households, including energy bills, exceed an amount that would permit them to purchase adequate amounts of other basic necessities. Although the housing industry has demonstrated its ability to produce large numbers of housing units, a significant proportion of households pays a disproportionate share of income for shelter or goes without adequate housing.

Household energy bills are the second largest housing cost, after rent or mortgage payments, making up about $16 \%$ of total housing costs on the average across all households. ${ }^{(\mathrm{c})}$ For lower income households, housing costs and the share that goes toward energy use pose special burdens. For example, very low income households spend an average of $47 \%$ of their income on housing costs and over one fourth of housing costs are due to energy bills. (d) Successful energy-efficiency and renewable-energy programs can reduce energy bills, but to improve affordability, especially for lower income households, these programs must do so without significant increases in purchase price, mortgage payments, rent, or down payments.

Affordable housing is a concern of all levels of government and an issue affecting many sectors of the economy. Consequently, affected stakeholders represent a broad national cross section.

For EE, the affordable housing issue can be related directly to the Office of Building Technology's mission. The Office of Technical and Financial Assistance (OTFA) also is directly affected by this issue

(a) Pacific Northwest Laboratory is operated by Battelle Memorial Institute for the U.S. Department of Energy under Contract DE-AC06-76RLO 1830.

(b) HUD defines "cost-burdened" differently for owned and rented housing: For owners, those spending more than $40 \%$ of their income on housing costs are cost-burdened and for renters the comparable figure is $30 \%$ (Prindle 1988).

(c) The authors calculated this statistic based on data from EIA (1993a) and HUD (1993).

(d) These statistics are derived from EIA (1993a) and HUD (1993). 
because of its weatherization programs and role in financing and incentives programs. This issue's scope and extent are so broad that it also interacts with the missions of the Office of Utility Technology, because utilities provide service to all households, and the Office of Industrial Technology (OIT), through its involvement with industries that could provide housing or housing components and materials. This paper provides much of the information needed to determine how the issue may influence the strategic direction of the office. 


\subsection{DEFINITION OF AFFORDABLE HOUSING}

There is no single definition of affordable housing. One of the most common and meaningful ways to assess housing affordability is in terms of what share of household income is required to cover the costs, including utility costs, of decent housing. This is the general approach used here.

Typically, housing affordability is an issue associated with lower income households. This issue paper adopts that perspective, but it is important to note that reducing utility costs can make "better" housing affordable to any household regardless of income.

\subsection{HOUSING COST AND INCOME}

In 1990 the median household annual income was $\$ 28,800$ (Grall 1993). Median annual housing costs were $\$ 7,180$ (Grall 1993). Figure 2.1 shows the distribution of households by income and how much of their income each income group spends on housing. According to HUD's definitions, 22.7 million households were "very low income" (with income less than $50 \%$ of the median) in 1990 , and 36.8 million were "low income" (less than $80 \%$ of the median income) (Irby 1986). Figure 2.1 shows that the proportion of household income spent on housing increases as income levels decrease. For the lowest income groups, the proportion increases dramatically.

For lower income households, several factors are important to keep in mind when considering affordable housing. Lower income household savings are lower and access to capital is limited. Implicit discount rates are typically high, thus these households

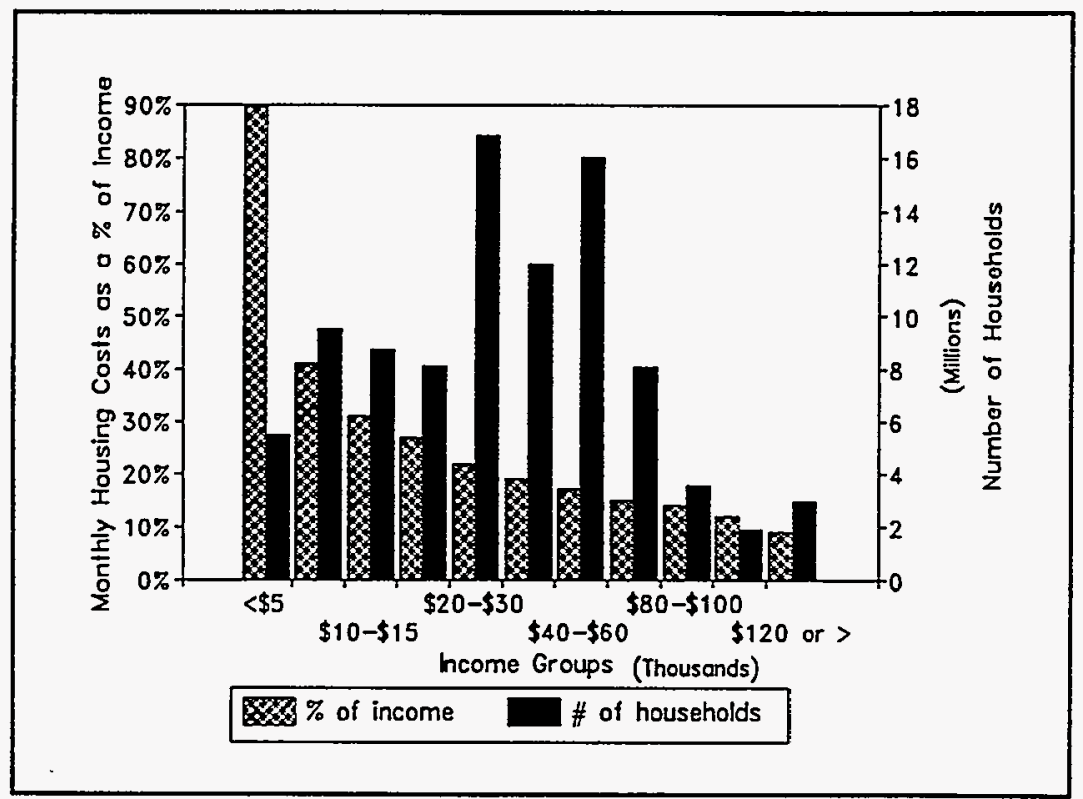

Figure 2.1. Housing Costs and Income Distribution require a relatively large rate of return on investments. This makes investments, such as in energy-efficiency measures that reduce future utility bills, difficult for lower income households to justify economically. These economic facts mean that the only viable housing option for the lowest-income households is often rental housing and, in many cases, subsidized or public housing. 


\subsection{HOUSING CATEGORIES}

Two major housing categories are rental and owner-occupied units. Approximately $36 \%$ of all households live in rental units and $64 \%$ live in owner-occupied housing. ${ }^{(0)}$ For lower income households, the proportion of rental units is higher: $48 \%$ of low income and $55 \%$ of very low income households are renters. Rental housing is predominantly multi-family housing (63\% of rental units are in multi-family buildings), while owner-occupied housing is predominantly single-family homes (92\%).

Mobile homes warrant special consideration. ${ }^{(b)}$ About $7.6 \%$ of owned homes are mobile homes; however, about twice this proportion of lower income households live in mobile homes. The lower costs of mobile homes often make them the most feasible way for households to transition from renting to home ownership, yet mobile homes are often less energy-efficient, and thus more expensive to heat and cool, than site-built homes.

Another important housing distinction is between new and existing homes. Of the current housing stock, $70 \%$ is 20 years old or older, $20 \%$ is 10 to 20 years old, $8 \%$ is 5 to 10 years old, and only $2 \%$ was constructed in the last 5 years. Older homes were generally constructed to lower efficiency levels than homes built under recent building codes. The lesser efficiency of older homes is a particular problem with lower income households; $80 \%$ of low income households live in homes 20 years or older, whereas only $63 \%$ of other households live in homes this old. To improve the efficiency of older homes requires investments in weatherization measures, which may be prohibitively expensive.

\subsection{COMPONENTS OF HOUSING COSTS}

Housing costs are usually defined in terms of monthly costs for shelter that the occupant must bear directly, and affordability is defined, in turn, relative to the household income. The full costs of housing, however, include the indirect costs that society at large must bear. Some of these indirect costs are transfer payments to subsidize the housing expenses of lower income households. Others are often referred to as externalities because they are external to the market for products and are not reflected in market prices. Such costs include future costs associated with the waste from construction sites, health effects from products used in the house, and health effects caused by air pollution from generating the electricity used by the household. These costs are rarely considered in determining housing costs and housing affordability, but they are real. Sustainable design and "green" buildings approaches are beginning to take these costs into account. As an example, the Environmental Protection Agency has a program to begin evaluating life-cycle environmental impacts of building materials (DOE 1994). Although this issue paper does not explicitly consider these costs, it recognizes that they merit increased attention in DOE's programs.

Because the size of utility bills, in particular those for energy, is influenced strongly by choices made during building design and construction, a life-cycle perspective on housing costs is important. Investment in energy-efficiency measures may increase purchase price, yet decrease future energy bills.

(a) The authors calculated the statistics for this section based on data from HUD (1993).

(b) In 1976, HUD created the HUD-code for homes called until then mobile homes. The proper name for homes built to this code is "manufactured homes." This paper uses the common term "mobile homes," however, because that is the term used in most housing statistical references. 
Lower income households, because of their lack of access to capital, difficulty meeting lenders' qualification requirements, and high discount rates, may be unable or unwilling to pay for efficiency increases and are faced with unnecessarily high future utility bills that reduce the actual affordability of their housing. Consequently, a life-cycle analysis of costs and benefits, which addresses first costs and future costs, should be the cornerstone for developing approaches to increase housing affordability.

Figures 2.2 and 2.3 illustrate the life-cycle for owner-occupied and rental housing, respectively. For owner-occupied housing, Figure

2.2 shows that the key participants are the designer/builder, buyer, and lender. The designer/builder makes key decisions during the design/construction process that affect energy use. The buyer makes key decisions in purchasing, occupying, furnishing, and reselling the home. In some cases, the owner influences energy-efficiency choices during design and construction. During occupancy, owners may upgrade their household energy efficiency by purchasing more efficient appliances and equipment or weatherizing their house. Other organi-

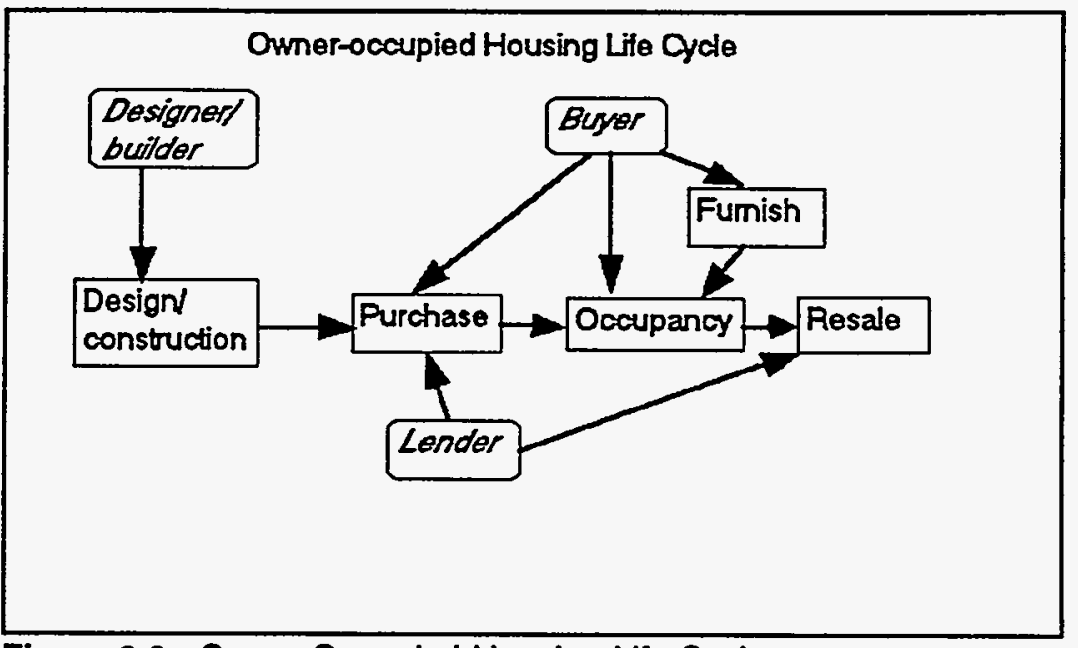

Figure 2.2. Owner-Occupied Housing Life-Cycle zations, such as local government, may assist with weatherization. The lender is influential in the original purchase and at resale, and may get involved in efficiency upgrades during occupancy.

Figure 2.3 shows similar steps during the life-cycle of rental housing. The key difference is that the owner is not the occupant and, consequently, many of the major decisions affecting energy use are not made by the occupant, the renter. Renters can upgrade household efficiency by purchasing more efficient appliances. They are less likely to weatherize their housing unit because they do not own it. Government agencies and other groups may assist landlords and renters in weatherizing rental units.

Direct housing costs include initial costs of moving into a home and ongoing costs of shelter. Moving-in costs, including down payments, can exclude some households from buying the home they desire or any home at all.

Monthly mortgage or rent payments are usually the largest component of monthly housing costs. Mortgage payments include principal and interest payments. While monthly mortgage or rent payments are what most people think of when considering housing costs, this view is inadequate because it neglects other costs, including energy costs, which may be a large proportion of total housing costs. 


\subsection{THE ROLE OF ENER- GY CONSUMPTION IN AFFORDABLE HOUSING}

The proportion of income spent on energy varies inversely with income. (a) For households above the low income level, energy costs are only $13 \%$ of total . housing costs. For very low income households, however, energy costs constitute about $26 \%$ of housing costs. Clearly, lower income households find housing less affordable relative to their income, and energy costs have a larger impact on affordability.

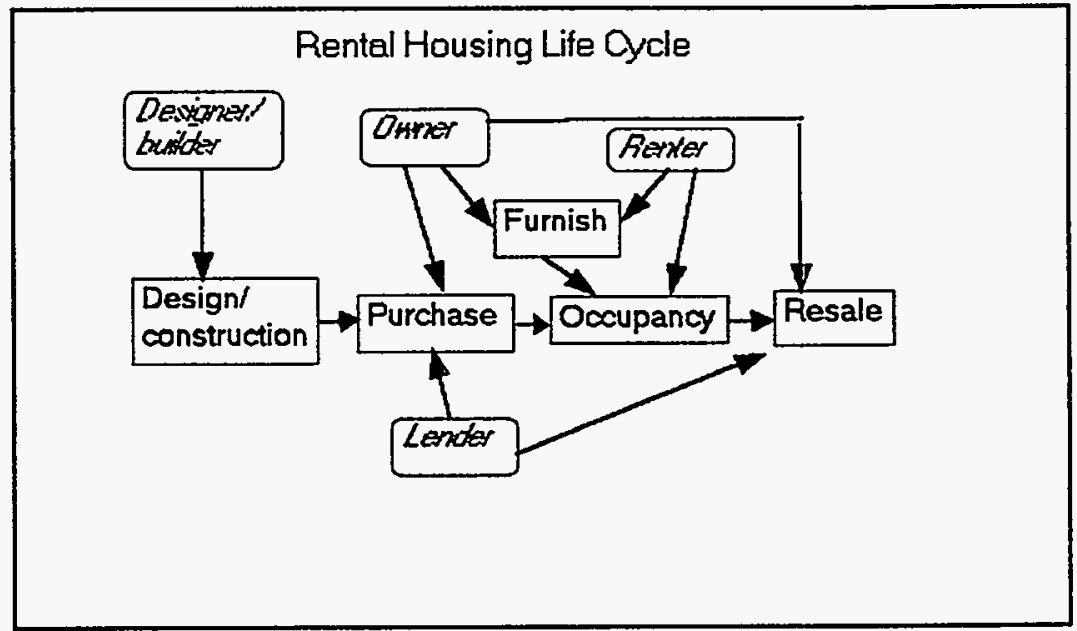

Figure 2.3. Rental Housing Life-Cycle

Somewhat surprisingly, average energy expenditures are dominated by miscellaneous appliances; for households, on the average, $35 \%$ of energy expenditures are for miscellaneous appliances, followed by space heating $(31 \%)$, water heating (14\%), refrigerators (11\%), and air conditioning (10\%). Figure 2.4 shows that expenditures by low income households follow a similar pattern by end-use; space heating costs, however, are slightly more than energy costs for appliances. Energy costs for all appliances, including refrigerators, are nearly $43 \%$ of the total energy costs of low income households. The relative contribution of each enduse to housing costs is climatedependent, so the focus of efforts to improve efficiency may need to differ by climate zone.

Two general mechanisms are available for improving the efficiency of energy use in lower income housing. The first is to reduce the amount of conventional energy required by lower income housing units and the products in them, while maintaining an appropriate comfort and service level. This can be done by increasing building and equipment

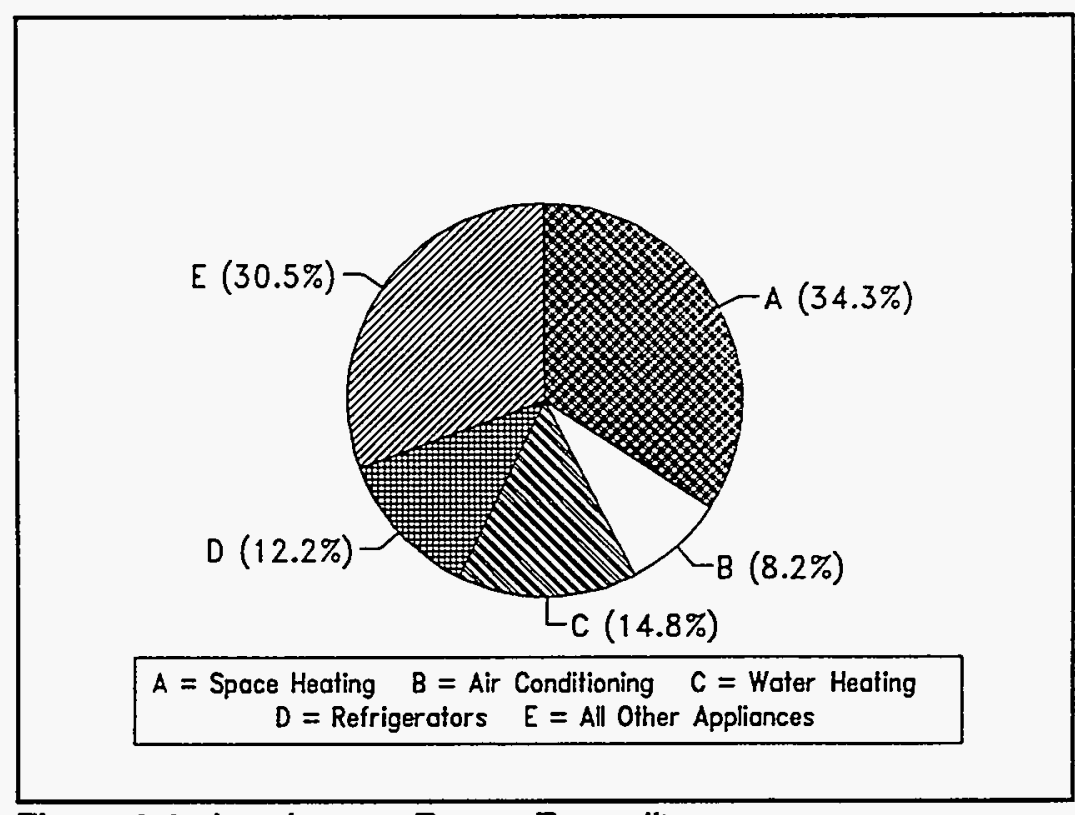

Figure 2.4. Low-Income Energy Expenditures

(a) The authors calculated the statistics in this section based on data from EIA (1993a) and HUD (1993). 
efficiency or by relying more on renewable, sustainable energy sources. Unfortunately, these steps may increase first cost, and higher first costs present a major hurdle for efforts to reduce the energy consumption in lower income households. Furthermore, in multi-family rental housing, which is the most common housing choice for lower income households, owners often have little incentive to invest in energy efficiency because they do not receive direct benefits. This aggravates the problems of improving energy efficiency for lower income households.

The second general mechanism is to educate and inform the user and buyer. Utility, state, and federal information programs can address this need. Specialized information needs may exist for lower income households. 


\subsection{HOUSING AFFORDABILITY FOR LOWER INCOME HOUSEHOLDS}

Housing characteristics, energy use, demographics, and economics all interact to determine the affordability of housing for lower income households. This section discusses these factors and their role in low income housing affordability. The appendix presents supplemental housing statistics and information that provide a context for the following discussion.

\subsection{HOUSING CHARACTERISTICS}

There are two main categories of homes: owner-occupied and renter-occupied. These categories are considerably different in characteristics as well as trends, and need to be treated separately. The differences will be more important as potential EE options are considered later in this paper, and programs will need to target these two specific groups.

A home is "owner-occupied" if the owner or the co-owner is a member of the household and the house is either paid off or mortgaged. Home owners, on average, live in larger homes, compared to renters, and have higher incomes. In 1991, 51\% of all families could not afford to buy a median-priced house (Savage and Fronczek 1993).

A home is "renter-occupied" even if the rent is paid by someone not living in the unit. This group includes "rent free" units which are not owned or being bought and no money is paid or contracted for rent. Renters earn less and spend more of their income on housing costs compared with owners. About $10 \%$ of renters receive some sort of federal, state, or local subsidy or live in public housing. ${ }^{(a)}$

Low income households occupy a much larger share of all rental housing than they do owner-occupied housing. Table 3.1 shows that between two thirds and three fourths of rental units are occupied by low income households in different parts of the country. Low income households occupy between one third and one half of owner-occupied housing. ${ }^{(b)}$

HUD defines three main housing unit types: single-family site-built homes (attached and detached), multi-family homes, and mobile homes (HUD-code manufactured homes). Single-family site-built homes make up $86 \%$ of the owner-occupied homes. These units typically consume the most energy per unit because of their larger average size. The most common housing type among renters is multi-family homes (63\%). Multi-family homes are structures with two or more units. Mobile homes and trailers are the last housing type. Although they represent a small share of overall housing, this type of home is

(a) The figures mentioned are the amount paid above any subsidies. The statistics in this section (excluding those in Table 3.1) were calculated by the authors based on data from HUD (1993).

(b) Northeast includes Maine, New Hampshire, Vermont, Massachusetts, Rhode island, Connecticut, New York, New Jersey, and Pennsyivania. Midwest includes Ohio, Indiana, Illinois, Michigan, Wisconsin, Minnesota, lowa, Missouri, North Dakota, South Dakota, Nebraska, and Kansas. South includes Delaware, Maryland, D.C., Virginia, West Virginia, North Carolina, South Carolina, Kentucky, Tennessee, Alabama, Mississippi, Arkansas, Oklahoma, Louisiana, Florida, Georgia, and Texas. West includes Montana, Idaho, Wyoming, Colorado, New Mexico, Arizona, Utah, Nevada, Washington, Oregon, California, Alaska, and Hawaii. 
Table 3.1. Percentage of Homes Occupied by Low Income Households ${ }^{(0)}$

\begin{tabular}{|l|c|c|}
\hline Region & Owner-Occupied & Renter-Occupied \\
\hline \hline Northeast & $36 \%$ & $66 \%$ \\
\hline Midwest & $44 \%$ & $74 \%$ \\
\hline South & $48 \%$ & $73 \%$ \\
\hline West & $35 \%$ & $65 \%$ \\
\hline (a) The authors calculated these statistics based on EIA (1993a.) \\
\hline
\end{tabular}

increasing in many parts of the country. These homes have traditionally been more common among lower income households. They are viable owner-occupied housing for lower income households because they are relatively inexpensive. However, mobile homes are exempt from local building standards and may consume more energy than comparable site-built homes.

Another important housing characteristic is vintage. On the average, older homes are less energyefficient than newer homes. The median income of households in homes built within the last 10 years is $30 \%$ higher than the median income of all home owners. Of renter-occupied units, only $9 \%$ are newer homes. Only $12 \%$ of low income home owners live in new homes and even fewer low income renters (3\%) live in newer homes. Typically, low income families live in older homes and end up paying more to heat every square foot.

\subsection{KEY STATISTICS RELATED TO AFFORDABILITY'}

Table 3.2 compares statistics for very low and low income households with data for other households. The income of very low and low income households is about $13 \%$ and $25 \%$, respectively, of the income of other households, and their dwellings are 11 and 9 years older, respectively. Lower income housing units are about one-third smaller, on the average, than those occupied by the higher income group. Lower income households are more than twice as likely to rent their homes as other households. Lower income households are between three and four times as likely to live in mobile homes.

Lower income households spend more than twice the proportion of their income on housing as other households. For about half the low income households, the share of income they spend on housing would put them above the housing cost-to-income ratio that most lenders use to determine qualification for a home loan. This makes it very hard for them to get financing to buy a home. The percentage of lower income households that are "cost burdened" by their housing costs is about five times as large for renters and over twice as large for owners as for other households. On the average, lower income households that rent pay about $\$ 120$ more per month for housing costs than lower income home owners (not shown in Table 3.2). Lower income households are far more likely to live in public or subsidized housing than other households. Consequently, the societal costs associated with meeting

(a) The authors calculated the statistics in this section based on data from EIA (1993a). 
Table 3.2. Comparisons by Income Group

\begin{tabular}{|c|c|c|c|}
\hline Characteristic & $\begin{array}{l}\text { Very low income } \\
\text { households }\end{array}$ & $\begin{array}{l}\text { Low income house- } \\
\text { holds }\end{array}$ & Other households \\
\hline Number of households & $23,710,000$ & $39,926,000$ & $53,221,000$ \\
\hline Median annual income & $\$ 7,990$ & $\$ 15,340$ & $\$ 61,982$ \\
\hline Avg. age of dwelling & 32 years & 30 years & 21 years \\
\hline Avg. size of dwelling, sq. ft. & 1,200 & 1,310 & 1,880 \\
\hline Share of households renting & $55 \%$ & $48 \%$ & $23 \%$ \\
\hline $\begin{array}{l}\text { Housing type, owned homes: } \\
\text { Single-family } \\
\text { Multi-family } \\
\text { Mobile home }\end{array}$ & $\begin{array}{l}80 \% \\
6 \% \\
15 \% \\
\end{array}$ & $\begin{array}{l}81 \% \\
6 \% \\
13 \% \\
\end{array}$ & $\begin{array}{l}91 \% \\
5 \% \\
4 \% \\
\end{array}$ \\
\hline $\begin{array}{l}\text { Housing type, rented homes: } \\
\text { Single-family } \\
\text { Multi-family } \\
\text { Mobile home } \\
\end{array}$ & $\begin{array}{l}30 \% \\
66 \% \\
4 \% \\
\end{array}$ & $\begin{array}{l}31 \% \\
65 \% \\
4 \% \\
\end{array}$ & $\begin{array}{l}39 \% \\
60 \% \\
2 \% \\
\end{array}$ \\
\hline $\begin{array}{l}\text { Share of income spent on } \\
\text { housing costs }\end{array}$ & $47 \%$ & $35 \%$ & $16 \%$ \\
\hline $\begin{array}{l}\text { Share of households "cost- } \\
\text { burdened": } \\
\text { Renters } \\
\text { Owners } \\
\end{array}$ & $\begin{array}{l}81 \% \\
41 \% \\
\end{array}$ & $\begin{array}{l}64 \% \\
29 \% \\
\end{array}$ & $\begin{array}{l}13 \% \\
14 \% \\
\end{array}$ \\
\hline $\begin{array}{l}\text { Share of households in public } \\
\text { or subsidized housing }\end{array}$ & $29 \%$ & $20 \%$ & $5 \%$ \\
\hline $\begin{array}{l}\text { Annual household energy use: } \\
10^{3} \mathrm{Btu} / \mathrm{sq} . \mathrm{ft} \text {. } \\
\$ / \text { sq. ft. }\end{array}$ & $\begin{array}{l}61 \\
0.71 \\
\end{array}$ & $\begin{array}{l}57 \\
0.69 \\
\end{array}$ & $\begin{array}{l}50 \\
0.62 \\
\end{array}$ \\
\hline $\begin{array}{l}\text { Household energy expendi- } \\
\text { tures: } \\
\text { Annual amount } \\
\text { Share of income } \\
\end{array}$ & $\begin{array}{l}\$ 938 \\
12 \% \\
\end{array}$ & $\begin{array}{l}\$ 1010 \\
7 \%\end{array}$ & $\begin{array}{l}\$ 1459 \\
2 \% \\
\end{array}$ \\
\hline \multicolumn{4}{|c|}{$\begin{array}{l}\text { Note: "Very low income" households include all those with incomes below } 50 \% \text { of the median; "low } \\
\text { income" households include all those with incomes below } 80 \% \text { of the median; "other" households are } \\
\text { those with incomes above } 80 \% \text { of the median. } \\
\text { (a) The authors calculated these statistics and those above it based on data from the U.S. } \\
\text { Department of Housing and Urban Development (HUD 1993). } \\
\text { (b) Statistics in last two rows are derived from Energy Information Administration (EIA 1993a). }\end{array}$} \\
\hline
\end{tabular}


housing needs of lower income households are far larger than the direct costs faced by these households would imply.

Table 3.2 also illustrates the role that energy use plays in housing affordability. Low income households consume $14 \%$ and very low income households consume $22 \%$ more energy per square foot than higher income households. These households spend $11 \%$ and $15 \%$ more, respectively, per square foot on energy than higher income households. Consequently, it appears that lower income housing is less efficient than other housing. In fact, the difference is probably understated because of forced energy savings that reduce energy bills, but sacrifice comfort.

Energy costs are a significant economic burden to very low and low income households. Although low income households pay only about $70 \%$ as much as other households for energy, energy costs are more than three times as large a share of their income. Very low income households pay six times as large a share of their income for household energy as households in the "other" income group.

It appears from these energy-use and cost data that the affordability issue is two-pronged. First, the buildings and appliances used by lower income households appear to be relatively inefficient. Second, monthly energy costs and the first costs associated with improving energy efficiency have larger relative impacts on lower income households because of their economic situation. In addition, the societal impacts may be understated if the government subsidies are not counted as costs.

The effects of energy use on affordability are also dependent on location. Table 3.3 shows that energy usage of low income households is the least in the West and the most in the Midwest, about $65 \%$ higher. The expenditure pattern is different, however; monthly energy costs are lowest in the West and highest in the Northeast, about $60 \%$ higher. The difference in energy expenditure between the West and Midwest is only about $39 \%$, compared with a $65 \%$ difference in energy use. The differences are due in part to the larger size of housing units in the Northeast, the contributions of different end uses to energy consumption and energy costs, and differences in energy prices. In the warmer regions, electricity costs for more air-conditioning and refrigerator use tend to offset reduced costs for space heating.

Table 3.3 Differences Across Census Regions for Low Income Households ${ }^{(0)}$

\begin{tabular}{||l|l|l|l|l||}
\hline \multirow{2}{*}{ Characteristic } & \multicolumn{4}{|c|}{ Census region } \\
\cline { 2 - 6 } & Northeast & Midwest & South & West \\
\hline $\begin{array}{l}\text { Monthly household energy } \\
\text { use (million British thermal } \\
\text { units (Btu)) }\end{array}$ & 8.5 & 9.3 & 6.0 & 5.7 \\
\hline $\begin{array}{l}\text { Monthly household energy } \\
\text { cost }\end{array}$ & $\$ 103$ & $\$ 89$ & $\$ 84$ & $\$ 64$ \\
\hline (a) The authors calculated these statistics based on data from ElA (1993b). & \\
\hline
\end{tabular}




\subsection{STAKEHOLDERS AND EXISTING PROGRAMS AND POLICIES FOR ENERGY-EFFICIENT AFFORDABLE HOUSING}

This section discusses the primary stakeholders and major existing programs and policies that affect affordable housing for lower income households.

\subsection{STAKEHOLDERS}

Table 4.1 identifies the primary stakeholders for owner- and renter-occupied housing.

Table 4.1 Stakeholders in the Owner- and Renter-Occupied Housing Market

\begin{tabular}{|l|l|}
\hline \hline \multicolumn{1}{|c|}{ Owner-Occupied Housing Market } & \multicolumn{1}{|c|}{ Renter-Occupied Housing Market } \\
\hline \hline Buyers & Renters \\
Designers & Designers \\
Home builders/manufacturers & Developers \\
Product/component suppliers & Product/component suppliers \\
Real estate agents and dealers & Real estate agents \\
Lenders & Apartment owners \\
HUD & Lenders \\
Local housing agencies & HUD \\
Utilities & Local governments \\
& Utilities \\
\hline \hline
\end{tabular}

\section{The Owner-Occupied Housing Market}

Many primary stakeholders influence the linkage between energy use and affordability in lower income owner-occupied housing:

- Buyers: The housing market operates to meet the needs and preferences of buyers. When buyers are looking for a home, affordability is an important consideration. However, buyers don't always take energy efficiency into account when they assess affordability.

- Designers: Designers are instrumental in determining the energy efficiency of homes, yet they have few incentives to design energy efficiency into new homes beyond code requirements.

- Home builders and manufacturers: These stakeholders supply the housing market with the stock of homes to meet buyer demand. Builders of site-built and factory-built housing will not build energy-efficient homes if there is no demand. They are also slow to change.

- $\quad$ Product/component suppliers: Many product suppliers have an interest in providing energyefficient products. Insulation, window, and equipment manufacturers often advocate the use of higher efficiency products. 
- Real estate agents and dealers: Real estate agents and manufactured home dealers play a big role in influencing buyers. They are responsible for displaying attractive homes to the buyers. Very few dealers and agents use energy efficiency as a selling point to the customers. Energy efficiency is usually treated as an additional feature.

- Lenders: Typically, lenders do not incorporate a measure of anticipated energy costs in determining whether a buyer qualifies for a mortgage on a specific home. Energy efficiency features may increase purchase price, which is included in the qualification determination, but reduce operating costs, which are not included. Energy expenditures contribute most to operating costs. Some lenders offer energy-efficient mortgages that help alleviate this problem.

- Department of Housing and Urban Development (HUD): HUD plays a significant role in the entire housing stock. HUD offers various programs and services including lending programs. Two types of HUD loans are Veteran's Administration loans (VA) and Federal Housing Administration loans (FHA). HUD also regulates the construction of manufactured housing.

- State, local, and community housing agencies: These stakeholders implement housing policies and operate weatherization programs in the local neighborhoods. Some assist in finding affordable housing for low income households.

- Utilities: Utilities arrange and provide energy and other utility service to houses. Utilities can use hook-up fees linked to consumption, demand-side management (DSM) programs, home energy rating systems (HERS), and other mechanisms to influence residential energy use. Utilities can benefit from home efficiency improvements by reducing arrearages.

\section{The Renter-Occupied Housing Market}

The renter-occupied housing market involves some different stakeholders. Its operation is considerably different from that of the home buyer's market:

- $\quad$ Renters: Although they may be able to infiuence the types of multi-family units being built, their influence is minimal. Most rental units are existing units, and if there are new units, they are already built, and renters must choose from that pool. Renter options and influences are very limited both by what is available and by their income since the majority of renters are lower income households. Most renters are responsible for their own utility bills and have little influence on how energy-efficient their unit is. They are often not interested in investing in energy conservation measures, partly because they cannot afford to, and also because they do not own the unit.

- Designers: Designers of rental units also have minimal incentives to incorporate energy efficiency beyond levels required by building codes, and they are often oriented toward reducing costs.

- Developers: Developers determine the supply of rental units. They develop multi-family buildings and supply renters with housing. Their main interest is in profit; consequently, they will keep building costs low and may sell their buildings off as soon as possible.

- $\quad$ Product/component suppliers: Suppliers have similar interest in energy efficiency in rental and owner-occupied units. 
- Real estate agents: In the renter-occupied housing market, real estate agents play a role similar to the role they play in the owner-occupied housing market.

- Apartment owners: Owners are also interested in profits. They rarely upgrade existing units or invest in energy-efficient measures. The majority of owners do not bear the cost of the utility bills and have little incentive to participate in any sort of retrofit or weatherization programs. However, there are incentive programs that may interest them in upgrading the building to higher energy-efficiency levels.

- Lenders: As with owner-occupied housing, lenders typically are not inclined to promote energy efficiency in rental units. They might consider energy-efficient rental property less risky, however, and be willing to offer buyers better lending terms.

- HUD: HUD offers various programs to assist low income households find shelter. Their biggest program is Section 8 through which they provide subsidies to help pay a portion of the rent according to household income. HUD also controls much of the public housing available. HUD Community Development Block Grants (HDBG) and other programs often provide a funding source for low income housing improvements, including weatherization.

- Local governments and agencies: As a service to utilities, local government offices operate specific programs such as multi-family weatherization programs. Community action agencies in some areas help lower income households find shelter and participate in weatherization programs. Local government agencies administer funding from the HDBG and other programs and often implement low income housing rehabilitation programs.

- Utilities: The role of utilities in rental housing is similar to that of utilities in the owner-occupied housing market. They provide incentives to the residential sector to change energy use and patterns. This may be a challenge in cases where renters are not responsible for their utility bills. Arrearages are a concern in low income, renter-occupied housing where renters are responsible for their utility bills.

\subsection{EXISTING PROGRAMS AND POLICIES AFFECTING ENERGY-EFFICIENT, LOWER INCOME AFFORDABLE HOUSING}

Programs and policies exist in virtually every level of government with respect to both housing affordability and energy conservation. Utilities and community groups are also involved. An examination of current programs and policies reveals many that influence energy conservation and housing costs for lower income households, while simultaneously highlighting missed opportunities. Lack of capital is an important factor limiting the number of affordable, energy-efficient residences, yet inaccessibility to information, low-cost technologies, and programs are also frequent stumbling blocks. Trends towards cooperative efforts, particularly on the local level, are encouraging.

\section{Department of Energy and Other Federal Programs}

A great number of federal programs exist that can impact energy-efficient, low income housing. This section briefly discusses three major federal programs that affect energy use by low income households.

\section{Weatherization Assistance Program}

The Weatherization Assistance Program (WAP), authorized by the Energy Conservation in Existing Buildings Act in 1976, aims to increase the energy efficiency of dwellings occupied by low income 
households, thereby reducing residential energy costs. DOE funds are allocated to states, where they are sometimes combined with utility contributions, the Low Income Energy Assistance Program (LIHEAP, see below), Petroleum Violation Escrow (PVE) account, and other funds and sub-allocated to local weatherization agencies. Program expenditures, limited to a statewide average of $\$ 1800$ per dwelling, which increases by three percent each year, are primarily devoted to measures that reduce air infiltration, increase insulation, and improve space heating and cooling efficiencies. Structural rehabilitation is not an allowable expenditure of the program, but some rehabilitation is necessary in the vast majority of weatherized homes. ${ }^{(2)}$ When structural rehabilitation is essential, the home will be referred to another agency like HUD.

\section{LIHEAP}

The Omnibus Budget Reconciliation Act of 1981 established LHEAP to assist eligible low income households in financing their home energy (heating or cooling only) requirements. The majority of this assistance is accomplished through direct subsidies, but administrators may choose to spend up to $15 \%$ of their annual budget on weatherization or repair programs. Roughly 9\% of LHHEAP's 1993 budget was allocated to weatherization measures.

The Clinton administration's budget proposal would have reduced the LIHEAP allocation from $\$ 1.437$ billion for FY94 to $\$ 0.73$ billion in FY95, and increased funding for the WAP from \$206.8 million to $\$ 249.8$ million. Congressional action, however, reduced the LIHEAP 1994 budget only about $8 \%$ and increased the WAP budget to only $\$ 226.8$ million (Energy and Housing Report 1994).

\section{Federally Assisted Housing}

Public housing units hold 3.4 million tenants, and one million more are wait-listed. The HUD Section 8 Public Housing Program employs two methods of rental assistance to increase housing affordability for low income households. For publicly owned properties, certificates are issued granting residence, where tenants pay a maximum of $30 \%$ of household income toward total housing costs. In privately owned buildings, vouchers are provided to subsidize the rental payments of households. Energy costs are a significant portion of the funds expended to operate publicly owned housing units, where consumption levels have historically exceeded those of privately owned apartments. Because funds for conservation improvements are limited, the Housing and Community Development Act (HCD) of 1987 authorized more flexible use of annual operating budgets to include energy-saving measures.

While energy conservation may not directly impact the housing costs of current public housing residents because of the $30 \%$ limit, savings would allow improvement or expansion of services. In privately owned buildings, rental-assistance vouchers subsidize housing costs, but do not limit household payments to $30 \%$ of their income. These households' expenditures are, therefore, affected directly by the energy requirements of their dwellings.

\section{Recent Federal Legislation and Initiatives}

Recent federal legislation and initiatives have targeted residential energy efficiency as central to two goals: increased opportunities for home ownership and the reduction of national energy consumption. Some of these actions modify existing programs and legislation.

(a) Incidental repairs can be done if they are critical to the performance of energy-efficiency measures. 


\section{National Affordable Housing Act}

The National Affordable Housing Act of 1990 (NAHA) directed HUD to improve residential affordability through a variety of programs, including mortgage incentives based on energy-efficiency ratings, conservation and efficiency grants, and rehabilitation loans. Energy-efficiency standards were ordered to be developed for construction of public and assisted housing as well as single-family and multi-family housing receiving HUD mortgages.

\section{Energy Policy Act}

The Energy Policy Act of 1992 (EPAct) contains several measures to increase access to, and reliance upon, energy efficiency codes, ratings and programs for residential buildings and fixtures that, in turn, may influence lower income housing affordability. Key activities include the following:

- $\quad$ Labeling: EPAct requires energy-efficiency rating labels for certain lamps and plumbing fixtures and initiates development of an updated voluntary labeling program for windows and window systems.

- New Homes: EPAct requires states to update their commercial building codes to meet or exceed ASHRAE Standard 90.1 (large multi-family dwellings are included in this category). Each state must also conduct a review of existing residential codes to determine whether it is appropriate to revise existing state codes to meet or exceed the Council of American Building Officials (CABO) 1992 Model Energy Code. Regardless of state codes, meeting or exceeding the 1992 Model Energy Code is a prerequisite for obtaining HUD-guaranteed loans.

- Existing Homes: EPAct expands on the concept of mortgage incentives introduced in the NAHA by requiring HUD to establish pilot programs in five states to promote issuance of Energy Efficient Mortgages (EEMs) and Energy Efficient Loans (EELs), for home improvements. The pilot programs, currently limited to existing attached or detached single-family residences, are to be expanded within two years to include new residential buildings and will be available nationwide, if determined practicable. The program is designed to integrate energy-efficiency considerations in the decision-making process for the two significant parties in the purchase of an existing home: the lender and the buyer. Lending authorities in participating states are required to provide written notice of EEM availability to all eligible mortgage applicants. In conjunction with this, the DOE will develop a HERS to provide a uniform scale of measurement and support issuance of EEMs and EELs. Procedures are to be established to ensure that HERS evaluations are available to potential buyers of residential property.

\section{Mobile (HUD-Code Manufactured) Homes}

Unlike site-built homes, mobile homes are not subject to state and local building codes, but are required to meet a national standard issued by HUD. The energy efficiency levels required by the HUD standard are considerably less stringent than those required by the CABO Model Energy Code. New standards, going into effect in October 1994, increase the stringency of the HUD code. Weatherization agencies report that although only $13 \%$ of the eligible population resides in mobile homes, $20 \%$ of the homes receiving weatherization assistance are mobile homes, which are often difficult and expensive to retrofit (Brown et al. 1993).

\section{Climate Change Action Plan (CCAP)}

DSM programs are featured prominently in the CCAP of 1993 . Several initiatives propose utilitysponsored energy efficiency programs as a key means of reducing greenhouse gas emissions. CCAP 
also reiterates the importance of EEM and HERS programs and proposes cooperative efforts among utilities and federal, state, and local agencies to generate the maximum energy savings from all programs. Although more than 60 sizable utilities have agreed to cooperate with the DOE to reduce emissions, changes within the utility industry may delay the process. If current trends result in more distributed and decentralized utilities, difficulties coordinating and funding DSM programs may impede their growth.

\section{Home Appliances}

Home appliances, which are estimated to account for over $20 \%$ of U.S. electricity consumption (EIA 1993), first came under federal regulation in 1987 with the passage of the National Appliance Energy Conservation Act (NAECA). The NAECA identified 13 classes of home appliances and established a schedule to set minimum efficiency standards for each category. The standards are re-evaluated periodically and increased, if feasible. Minimum standards pertain only to new appliances and, therefore, have a limited effect on the majority of low income consumers, who purchase new or replacement appliances infrequently. Tightening the efficiency standards does, however, raise the average efficiency of appliances in use and will provide significant long-term benefits to all households.

\section{State and Local Programs and Policies}

State and local governments and organizations are key participants in delivering affordable, low income housing. For many years, they have been instrumental in implementing DOE's WAP and LIHEAP and HUD's CDBG program. Recent federal programs and legislation rely on local entities to carry out key actions to enhance the affordability of low income housing. Many localities have already implemented exemplary programs that can provide a model for other parts of the country. Some state and local activities are discussed below.

\section{Pilot Lending Programs}

In accordance with the directives in EPAct, six states ${ }^{(2)}$ have established pilot lending programs to encourage the purchase of existing energy-efficient dwellings and to promote installation of cost-effective improvements. The states were chosen to participate partially on the basis of HERS programs that each had previously established.

\section{Home Energy Rating Systems}

A number of state and local agencies have developed HERS, frequently run in conjunction with local utilities. The systems are usually scaled for both new and existing homes.

\section{Building Codes}

The majority of states have not yet completed reviews or revisions of existing state building codes as required by EPAct. The DOE has sponsored several regional workshops to assist states in reviewing, upgrading, implementing, and enforcing building energy codes.

(a) The number has increased from the five programs originally mandated. 
Several municipalities have successful energy-efficiency programs designed to benefit low income residents. Frequently these programs are conceived and administered in cooperation with local utillties. The City of Portland Energy Office, for example, offers assistance to owners and managers of multifamily properties by providing access to energy audits, cash rebates, tax credits and loans. San Francisco has ordinances requiring that properties meet minimum energy-efficiency levels at time of sale. In Chicago, a partnership of local governmental agencies, utilities and community organizations tests and corrects bulidings' "balancing." This problem occurs frequently in older buildings (uneven heating causes tenants closest to the boiler to open windows, while those farthest from the boiler remain cold) and wastes a considerable amount of energy.

\section{Utility Programs}

Utilities, facing the high costs of prospective increases in capacity and under pressure to decrease emissions, have developed DSM programs to reclaim some portion of the electricity lost to inefficient end-usage. DSM programs utilize conservation and load management technologies to reduce or alter demand patterns while preserving levels of sevice. There are an estimated 18 million residential customers participating in over 700 individual DSM programs targeting household consumption. Of these, roughly 200 programs involve multi-family dwellings and 500 apply to single-family residences. The breadth and depth of the programs vary widely, the most common involving weatherization measures, new construction efficiency standards, rebates for purchases of energy-efficient appliances, or incentives to minimize peak-load consumption. Certain programs specifically target the needs of low income customers, while many others contain income-based subsidies or grants.

Despite success in reducing and managing electricity demand, many utilities have begun to phase out DSM programs. The high cost of developing and implementing DSM programs, combined with the resultant decrease in sales revenue and recent regulatory and industry changes, have forced many utilities to discontinue programs. Similarly, utility contributions to the WAP, a significant source of funding, dropped from \$44 million in 1990 to approximately \$21 million in 1993.

\section{Non-Profit Homebuilders}

Limited profit potential discourages many builders from constructing small, modestly priced housing. This has contributed to the growth recently of non-profit residential construction organizations that build inexpensive homes for low income households. A leader in this area, Habitat for Humanity, is currently ranked as the 17th largest home builder in the U.S. and is predicted to be among the ten largest within a few years. Habitat for Humanity is close to completion of a pilot project incorporating energy-efficient technologies in the construction of a 200-home community in Dade County, Florida. Energy-efficient technologies employed in the homes include solar water heaters, heat-reflective roof paint, and daylighting through clerestories. Each new home is expected to consume $45-65 \%$ less energy than a conventional home of similar dimensions.

\section{Lessons from Existing Programs}

Weatherization can provide substantial reductions in housing costs, national fuel consumption, and greenhouse gas emissions. A study of dwellings weatherized in the 1989 WAP found the average household saved $\$ 116$ on energy bills over the following year; the combined energy savings of these households, in just one year, equates to approximately 601,000 barrels of oil (Brown et al. 1993). 
Further savings may be possible if household appliances are refurbished, repaired or replaced. As noted earlier, energy use of all appliances accounts for approximately $43 \%$ of energy costs for low income households, yet regulations (and costs) discourage the WAP from refurbishing or replacing appliances. (s) A promising exception to this policy is the 1993 amendment permitting air conditioner replacements and tune-ups in warm regions. In many households, refrigerators are among the least efficient users of energy, particularly if poorly maintained. While stringent regulations have brought drastic improvements in the efficiency of new units, old models are still used widely, either as primary or secondary units. Aged units consume up to four times more energy than newer models. Several utilities have instituted "second refrigerator" collections or buybacks to relieve customers from the burden of disposal and reduce their energy bills by as much as $\$ 150$ per year.

Strict appliance standards have brought about considerable advances in refrigeration, lighting and airconditioning efficiency levels over the last 20 years. Further improvement in air-conditioning standards, however, is currently limited because higher efficiency requires expensive components, such as variablespeed motors. The seasonal energy efficiency ratio of the most efficient units ( $>16$ British thermal units per watt-hour (Btu/Wh)) is significantly higher than that required by federal standards (10 Btu/Wh).

Utilities' DSM programs have promoted adoption of more stringent building codes in several states. Programs have included technical training and information sessions, publicity efforts to stimulate buyer demand for energy-efficient buildings, and financial incentives for builders who voluntarily exceed code.

The existence of a preemptive national standard for manufactured homes led the Bonneville Power Administration to coordinate a voluntary energy-efficiency program among manufactured home builders, dealers, utilities, consumers and policy makers in the Pacific Northwest. A major success, the Manufactured Housing Acquisition Program (MAP) caused virtually every new electrically heated manufactured home sited in the Pacific Northwest to be built to high energy-efficiency levels.

(a) The authors calculated this statistic based on data from EIA (1993a). 


\subsection{POTENTIAL OPTIONS FOR OFFICE OF ENERGY EFFICIENCY AND RENEWABLE ENERGY}

The previous discussion suggests that housing affordability needs to be a key consideration in EE's strategic direction. Nearly one third of all households are cost-burdened by housing costs. For low income households, energy costs are one fifth of total housing costs. A large infrastructure of federal and local government and private sector participants exists to address housing needs of lower income households. Unfortunately, energy use and efficiency improvements in lower income housing are often inadequately addressed or are the subject of potentially conflicting policies and programs. The special circumstances of lower income households, including lack of access to capital, high discount rates, lack of information, and the influence of housing subsidies, make the problem of improving energy utilization more complex than for other households.

EE's Draft Strategic Plan (EE 1994) identifies three interdependent strategies for its programs: continuously advancing technologies, mobilizing markets, and managing for success. Within these three strategic thrusts, EE can implement specific actions to make housing more affordable, particularly for lower income households. This section presents potential options for EE actions within the three general strategy areas.

The special characteristics of lower income housing generate several needs for improving housing affordability. These needs include the following: reduced first cost, improved housing and equipment efficiencies, consideration of the full life-cycle and environmental impacts, special requirements of lower Income housing, consideration of societal impacts and equity for all income groups, and provision of relevant information for consumers and others. The options presented here respond to these needs, recognize the existing infrastructure that influences lower income housing, and build on existing programs where possible. Each option is categorized by whether it requires short-term or long-term investment. Based on the authors' judgment and the information presented in this report, each option is also assigned to a priority category, ranging from 1 to 3 , with 1 being the highest priority category.

\subsection{TECHNOLOGY STRATEGY: CONTINUOUS ADVANCEMENT}

Need: Reduced first cost

Option: Increase emphasis on low-cost, no-cost efficiency and renewables technologies In the past, EE has emphasized technological advancement over cost reductions, but increased research on significant cost reductions in efficiency and renewable energy technologies could improve housing affordability. Cost reductions for insulation materials, window glazings, and efficient appliances could reduce the first-cost impediment faced by lower income households. Factory-built housing and components may offer opportunities for reducing costs of energy-efficient housing. Emphasis on low-cost passive solar building design and thermal storage technologies might produce significant energy bill savings for lower income households for small up-front costs.

Investment: Long term

Priority: 1 
Need: General improvements in housing and equipment efficiency

Option: Develop technologies and tools that enhance code compliance and enforcement The effectiveness of efficiency codes and standards is limited by how well they are followed and enforced. Tools to facilitate builder/manufacturer compliance with codes in multi-family buildings and manufactured homes could have a large impact on the energy consumption of lower income housing. Tools that help inspectors verify compliance could also assure that occupants achieve expected energy savings.

Investment: Short term

Priority: 2

Option: $\quad$ Upgrade data and information for appliance standards

Standards provide a minimum efficiency baseline that protects all consumers. Research that generates the data needed to upgrade a wide range of appliances could benefit lower income households when they purchase new appliances.

Investment: Short term

Priority: $\quad 3$

Need: Consideration of full life-cycle and environmental impacts

Option: Develop tools for analyzing life-cycle and fuel cycle impacts of lower income housing Tools and information that are being developed to assess the sustainability of housing alternatives could be modified to take the special characteristics of lower income housing into account. For example, the life-cycle of multi-family and manufactured housing could be addressed explicitly. This would assist EE in developing comprehensive policies and programs to meet affordable housing needs.

Investment: Long term

Priority: 2

Option: Gather, compile, and analyze data on a full range of resource use associated with lower income housing

A fuller understanding of the energy and resource use of lower income housing requires data beyond those currently available. Information on the use of specific fuels, energy consumption of various end-uses, and water consumption is needed.

Investment: Long term

Priority: 2

Need: Special requirements of lower income housing

Option: Develop improved technologies to upgrade existing housing and appliances Because a disproportionate share of lower income households resides in older homes, weatherization technologies are essential in efforts to increase housing affordability. Low-cost technologies that can be installed or steps that can be taken in existing housing may be very cost-effective. Inexpensive ways to improve the efficiency of existing refrigerators, air-conditioners, and appliances, possibly during routine weatherization, could be especially cost-effective. Ways to improve air-handling systems and exterior ducting in existing housing also could be very productive.

Investment: Long term

Priority: 1 
Option: Develop retrofit technologies tailored to manufactured and multi-family housing Manufactured homes, especially older ones, pose unique problems for efficiency retrofits. Technologies and materials that would facilitate retrofits are needed. Multi-

Investment: family buildings also may pose unique problems or opportunities for efficiency upgrades that could be addressed through new technologies.

Priority: 3

Need: Consideration of societal impacts and equity

Option: Develop tools for analyzing impacts on lower income households

Lower income households and their housing units differ substantially from the societal average. These differences could be taken into account in existing analytic models. In particular, the discount rates, access to capital, knowledge, and preferences of lower income households could be studied and incorporated in models used to estimate impacts of EE's programs and policles. Other influences such as the energy

Investment: Short term impacts of geographic location could be incorporated in the models.

Priority: 2

Need: Provision of relevant information to consumers and others

Option: Identify key information needs of lower income households and rental property owners and develop necessary materials

The information needs of lower income households about energy use and efficiency differ from the needs of the population at large. Utilities and others have identified some of the differences. This information could be compiled, organized, and supplemented. This would provide the basis for developing appropriate materials to meet the information needs. Because the energy-efficiency interests of renters and rental property owners do not necessarily coincide, it is also important

Investment: Long term to emphasize development of materials targeted at rental property owners.

Priority: 2

Option: Improve data collection associated with WAP Effectiveness of the program and delivery of weatherization services to lower income households could be improved by improving consistency, timeliness, and completeness of data collection to support implementation and evaluation of WAP.

Investment: Short term

Priority: 2

\subsection{MARKET STRATEGY: MOBILIZING MARKETS}

Need: Reduced first cost

Option: Develop programs to promote low-cost efficiency and renewable technologies Collaboratives with industry, utilities, and others could be established to promote development of low-cost technologies. EE could sponsor competitions, like the Super Efficient Refrigerator Program, for the development and production of low- and nocost technologies that would be suitable for applications in lower income housing. 
Investment: Short term

Priority: $\quad 1$

Option: $\quad$ Establish loan programs for energy-efficiency upgrades to lower income housing Low or no-interest loans to lower income families and owners of lower income housing could help overcome the first-cost barrier to efficiency investments. EE might collaborate with utilities to target the kinds of upgrades that would be eligible.

Investment: Long term

Priority: 3

Need: General improvements in housing and equipment efficiency

Option: $\quad$ Accelerate and expand adoption of building and appliance efficiency standards Although lower income households are less likely than other households to occupy new homes and purchase new appliances, efficiency standards will upgrade the minimum efficiency levels of all buildings and appliances in the long-run. Extending standards to additional appliances and equipment could reduce the share of energy used by them and reduce overall energy costs.

Investment: Short term

Priority: 1

Option: Design and implement market transformation programs emphasizing lower income households

Market transformation programs aim to permanently increase the efficiency of selected products or systems, usually through short-term funding or incentives. Such programs should be conducted in a way so that they increase the efficiency of a wide line of products, not just top-of-the-line products that only higher-income households can afford. EE could work with utilities, builders, and manufacturers to design approaches that improve the efficiency of lower priced products.

Investment: Long term

Priority: $\quad 1$

Option: Improve lending terms for lower income households to purchase energyefficient housing

DOE could collaborate with HUD and lenders to design and implement programs that include lower interest rates, reduced down-payment requirements, extended loan terms, and more flexible loan qualification criteria for energy-efficient homes. Mechanisms could be established that would reduce the risk exposure faced by lenders.

Investment: Long term

Priority: 1

Option: Implement programs to upgrade the efficiency of existing buildings when they are sold

DOE could collaborate with local governments and utilities to demonstrate model programs that upgrade the energy efficiency of multi-family buildings when they are sold.

Investment: Long term

Priority: 3 
Need: Consideration of full life-cycle and environmental impacts

Option: Implement programs to promote lower income sustainable housing

DOE could provide the analysis needed to increase the sustainability of lower income housing. The consumption of all fuels and other resources, such as water, should be included in the analysis. Guidelines, such as those developed by the EPA, for sustainable building design and construction could be applied to the design and construction of lower income housing. Use of recycled and recyclable materials in government-funded housing could be required.

Investment: Long term

Priority: 1

Option: Continue to shift emphasis from subsidizing energy bills to making permanent efficiency improvements

Housing and energy programs that subsidize energy expenditures provide no incentive to make efficiency improvements that will have long-term benefits, reducing the need for continuing subsidies. Shifting subsidies to investments in energy efficiency can have significant public benefits.

Investment: Long term

Priority: 1

Option: $\quad$ Conduct programs to incorporate cost-effective, renewable resource use in lower income housing

Although renewable resources can have high first-costs, some technologies, such as passive solar heating, may be relatively inexpensive to incorporate. EE could also

- work with lending institutions and other federal and local agencies to implement

Investment: Long term programs to help finance the costs of renewable resources.

Priority: $\quad 2$

Need: Special requirements of lower income housing

Option: Incorporate significant efficiency improvements into lower income housing during major rehabilitation

DOE could work with HUD, local agencies, utilities and others to incorporate such improvements during lower income housing rehabilitation projects.

Investment: Long term

Priority: $\quad 1$

Option: $\quad$ Create programs to improve the efficiency of new, lower income housing DOE could collaborate with HUD, local housing agencies, non-profit builders, and others to improve the efficiency built into new housing. Mechanisms could be identified and implemented to remove the barriers to energy-efficiency investments that rental-unit owners face. Possible ways that lower income households could lease-to-own efficient housing could be examined.

Investment: Long term

Priority: 2

Option: Expand the efficiency improvements that occur during weatherization The WAP and other weatherization efforts could be expanded to include appliance replacements and upgrades to improve energy efficiency. Additional measures could 
Investment: Short term

be included in the program and more emphasis could be placed on the specific needs of homes in hot climates. DOE could work with utilities and local agencies to implement these changes.

Priority: 2

Option: Improve efficiency and reduce costs of efficient factory-built housing DOE could collaborate with the HUD-code manufactured housing industry, dealers, and utilities to develop programs to improve the efficiency of manufactured homes significantly. DOE could work more with all segments of the factory-built housing industry to use the inherent economies of factory production to reduce the cost of energy-efficient, lower income housing. Mechanisms to overcome the first-cost barrier

Investment: Long term could be designed and implemented.

Priority: 2

Need: Provision of relevant information to consumers and others

Option: $\quad$ Develop educational and promotional materials and delivery mechanisms for lower income households and rental property owners

Materials explaining the economic, environmental, and other benefits of reduced energy use could be developed. Review of such materials could be a condition for receiving a rebate or incentive.

Investment: Short term

Priority: 2

Option: $\quad$ Accelerate the adoption of home energy rating systems

Such systems can provide effective information for communicating the benefits of energy efficiency. The information, in turn, can be used to market more efficient housing. Non-energy savings benefits, such as environmental impacts, could be incorporated in such systems.

Investment: Short term

Priority: 2

\subsection{ORGANIZATIONAL STRATEGY: MANAGING FOR SUCCESS}

Need: Reduced first cost

Option: Increase the importance of cost reductions in EE's organizational objectives DOE could place greater emphasis on reducing costs of efficiency improvements and renewable resource applications. This would make products more useful in the nearterm.

Investment: $\quad N / A$

Priority: 1

Need: Consideration of full life-cycle and environmental impacts

Option: Incorporate environmental and sustainability considerations in EE's organizational goals and culture

Investment: N/A

Priority: 2 
Need: Consideration of societal impacts and equity

Option: $\quad$ Adopt a goal of promoting equitable, affordable housing

Investment: $N / A$

Priority: 1

Need: Provision of relevant information to consumers and others

Option: Include sustainability and equitable housing-affordability goals in EE's Quality Metrics process and fully implement their use in planning and budgeting Measuring progress in these areas will help EE target future activities to address affordable housing and will inform DOE and others about how much progress has been made.

Investment: $N / A$

Priority: 2 


\subsection{INFORMATION AND ANALYSIS NEEDS}

Through the efforts of the U.S. Census Bureau, DOE, and HUD, a considerable amount of information is available on housing in this country. This abundance of housing data makes it possible to examine many dimensions associated with affordable housing. There are areas, however, in which additional Information and analysis could improve our understanding of the overall issue of affordable housing:

- Low- and no-cost efficiency improvements: Lower income housing affordability could benefit from comprehensive information on low cost methods and materials for increasing energy efficiency and use of renewable energy in new and existing homes.

- Housing market assessment: Better information on the preferences and behavior of lower income households and property developers and owners would help design and target programs.

- Housing energy use: Better data on how energy is used in lower income housing would benefit efforts to target efficiency improvements. Further analysis of appliance energy use would help identify the best opportunities and mechanisms for reducing appliance energy use.

- Program reporting: More complete and consistent reporting on weatherization and other programs would be helpful in efforts to improve these programs.

- Life-cycle and environmental impacts: In general, improved information on the life-cycle and environmental effects of different construction techniques, materials, and retrofit strategies would help in efforts to take a comprehensive perspective on affordable housing based on sustainable building principles. 


\section{REFERENCES}

Brown, M. A., L. G. Berry, R. A. Balzer, and E. Faby. 1993. National Impacts of the Weatherization Assistance Program in Single-Family and Small Multifamily Dwellings. Prepared by Oak Ridge National Laboratory for the Weatherization Assistance Programs Division, U.S. Department of Energy, Washington, D.C.

Energy and Housing Report. September 1994. 'FY'95 Housing Energy Budget to Rise from FY'94 Level, LIHEAP Funds to Drop." 14(9):3.

Energy Information Administration (EIA), Office of Energy Markets and End Use. 1993a. Household Energy Consumption and Expenditures 1990. U.S. Department of Energy, Washington, D.C.

Energy Information Administration (EIA), Office of Energy Markets and End Use. 1993b. Household Energy Consumption and Expenditures 1990, Supplement: Regional. U.S. Department of Energy, Washington, D.C.

Energy Information Administration (EIA), Office of Energy Markets and End Use. 1992. Housing Characteristics 1990. U.S. Department of Energy, Washington, D.C.

Energy Policy Act of 1992. Public Law 102-486, 106 Stat. 2777-3133.

Grall, T. S. 1993. Our Nation's Housing in 1991. Bureau of the Census, Current Housing Reports, Series H121/93-2, U.S. Government Printing Office, Washington, D.C.

Housing and Community Development Act of 1987. Public Law 100-242, 101 Stat. 1815.

Irby, I. July 16, 1986. "Attaining the Housing Goals?" U.S. Department of Housing and Urban Development, Washington, D.C.

National Affordable Housing Act of 1990. Public Law 101-625, 104 Stat. 4079.

National Appliance Energy Conservation Act. Public Law 100-12, 101 Stat. 103.

Office of Energy Efficiency and Renewable Energy. 1994. Draft Strategic Plan. U.S. Department of Energy, Washington, D.C.

Prindle, W. R. and M. W. Reid. 1988. Making Housing More Affordable Through Energy Efficiency. The Alliance to Save Energy, Washington, D.C.

Savage, H. A. and P. J. Fronczek. 1993. Who Can Afford to Bury a House in 1991? H121/93-3, U.S. Bureau of the Census, Current Housing Reports, U.S. Government Printing Office, Washington, D.C.

U.S. Department of Commerce and U.S. Department of Housing and Urban Development (HUD). 1993. American Housing Survey for the United States in 1991. Series H150/91, U.S. Bureau of the Census, Current Housing Reports, U.S. Government Printing Office, Washington, D.C.

U.S. Department of Housing and Urban Development (HUD). 1990. The United States Department of Housing and Urban Development Annual Report. HUD-329-PA(19), U.S. Government Printing Office, Washington, D.C. 


\section{BIBLIOGRAPHY}

BioCycle: The Journal of Waste Recycling. July, 1992. "Appliance Recycling Takes Off." 33(7):48-49.

Clinton, W. J. and A. Gore, Jr. 1993. The Climate Change Action Plan. The White House, Washington, D.C.

Electrical World. January, 1994. "DOE Pushes Greenhouse-gas Reduction." 208(1):23-24.

Electrical World. May, 1994. "West Coast Utilities' Recycling Plan Could Cut Demand by 34 MW." 208(5):27.

Energy and Housing Report. February, 1994. "State Code Inaction Angers Rep. Dicks." 14(2):1.

Energy and Housing Report. June, 1994. "Low-Income Hurricane Andrew Victims to Get New EnergyEfficient Homes." 14(6):1.

Energy Information Administration (EIA), Office of Energy Markets and End Use. 1989. Household Energy Consumption and Expenditures 1987. U.S. Department of Energy, Washington, D.C.

Harney, K. R. April 24, 1993. "Linking Mortgages, Energy Efficiency," Washington Post, p. 1.

Hummel, P. and J. Kesselring. December, 1992. "Impacts of Appliance Efficiency Standards," EPRI Journal, pp. 41-45.

Katz, J. April 23, 1994. "HUD Plan to Shift Funding Draws Sharp Criticism." Congressional Quarterly Weekly Report, 52(16):1008.

Lewis, T. A. December/January, 1993. "The States Seize Power." National Wildlife, pp. 17-19.

Lovins, A. 1992. Energy-efficient Buildings: Institutional Barriers and Opportunities. E Source, Inc., Boulder, Colorado.

Mihlmester, P. E., W. C. Koehler, Jr., M. A. Beyer, M. A. Brown, and D. A. Beschen, Jr. 1992. Characterization of the Weatherization Assistance Program Network. ORNL/CON-324, Oak Ridge National Laboratory, Oak Ridge, Tennessee.

Oak Ridge National Laboratory. 1992. Energy Performance Contracting for Public and Indian Housing. Prepared by Oak Ridge National Laboratory for The DOE-HUD Initiative, Washington, D.C.

Pacific Northwest Laboratory. August, 1994. Utility Programs: Supporting Adoption and Enforcement of Energy Codes for New Building Design and Construction. Prepared by Pacific Northwest Laboratory for the Office of Codes and Standards, U.S. Department of Energy, Washington, D. C.

Ramos, D. March 14, 1994. "HUD-dled Masses." New Republic, pp. 12-16.

Robinson, G. April 5, 1993. "Appliance Makers Meet Tomorrow's Standards Today." Design News, pp. 66-73. 
Sandahl, L. J., M. P. Hattrup, A. D. Lee, and S. A. Onisko. 1992. Energy-Efficient Manufactured Homes: The Role of Lending and Appraisal Practices. PNL-8319, prepared by Pacific Northwest Laboratory for the Bonneville Power Administration, Portland, OR.

U.S. Department of Energy (DOE). 1994. Federal User's Manual-Performance Standards for New Commercial and Multi-Family High-Rise Residential Buildings. U.S. Government Printing Office, Washington, D.C.

U.S. Department of Energy (DOE). 1990. Report to Congress on the Fiscal Year 1990 Low Income Home Energy Assistance Program. U.S. Government Printing Office, Washington, D.C.

Utility Data Institute (UDI). 1993. The Official Guide to Demand Side Management Programs \& Research. UDI/McGraw-Hill, Washington, D.C.

Williams, C. April, 1994. "Teaching Old Systems New Tricks," Nation's Cities Weekly, p. 7. 


\section{APPENDIX}

SUPPLEMENTAL HOUSING INFORMATION 


\section{APPENDIX \\ SUPPLEMENTAL HOUSING INFORMATION}

There are two main categories of homes: owner-occupied and renter-occupied. Owner-occupied homes make up the majority $(64 \%)$ of the nation's housing stock, while the rest is renter-occupied. The typical home owner is 46 years old with a median income of $\$ 34,800$. Home owners, on average, live in larger homes, compared to renters, and have higher incomes. The typical renter is 37 years old, with a median income of $\$ 20,296$, almost $\$ 15,000$ less than the typical home owner, and spends $28 \%$ of income on housing costs (Grall 1993).

Figure A.1 shows the home types and their distribution in the stock of owner-occupied homes ${ }^{(0)}$. Figure A.2 shows that the most common housing type among renters is multi-family homes $(63 \%)$. Mobile homes are twice as common among owners as they are among renters.

Table A.1 shows that the percentage of all homes that are owner-occupied is fairly uniform across the four census regions, the highest portion found in the Midwest (67\%) and lowest in the West (59\%). The opposite is true for renter-occupied units with the highest proportion found in the West, and the lowest in the Midwest.

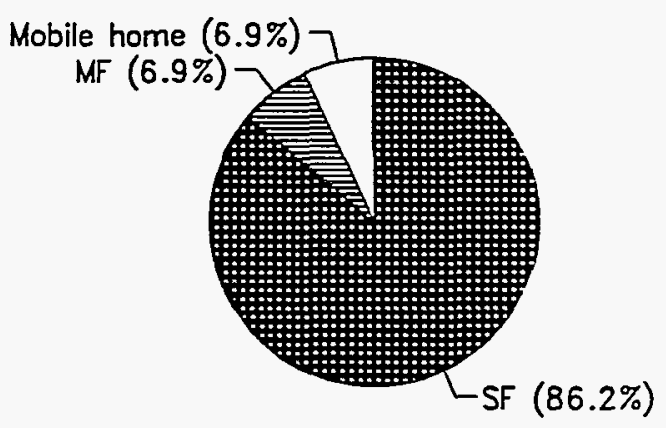

The distribution of housing types for owner-occupied homes is failly uniform across the four regions, with single-family units making up the majority of the owned housing stock (about $85 \%$ ). The largest

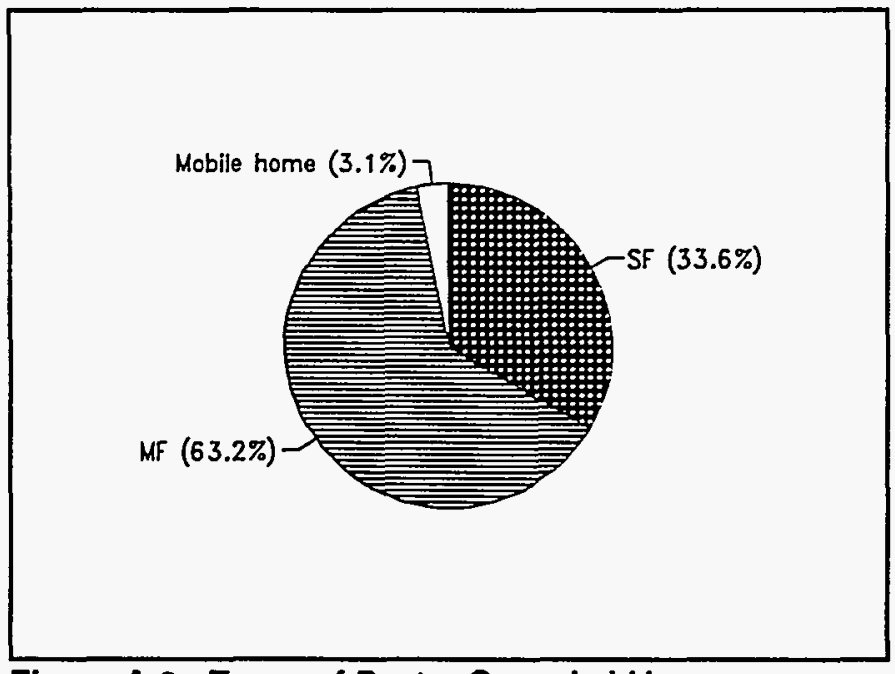

Figure A.2. Types of Renter-Occupied Homes share of multi-family homes is found in the Northeast (13\%). Mobile homes make up the largest share in the South (11\%) while they make up the least in the Northeast (4\%).

The distribution of renter-occupied units differs somewhat by region; however, the majority in all four regions is multi-family homes. The highest proportion of multi-family units is found in the Northeast (91\%) and the lowest is in the South $(53 \%)$.

The percentage of income an owner-occupied household spends on housing is fairly uniform across the regions, with the median being roughly $16 \%$. Compared with the rest of the country, the South has the lowest median owner-occupied household income,

(a) The authors calculated the statistics in this appendix based on data from HUD (1993). 
$\$ 31,114 /$ year. The highest is in the West, $\$ 41,857 /$ year. Median housing costs for owner-occupied households are highest in the West $(\$ 604 /$ month) and lowest in the South ( $\$ 362 /$ month). Figure A.3 compares these statistics with those of renters by region.

Table A.1 Summary of Housing Distributions

\begin{tabular}{||l|c|c|c|}
\hline Region & Type of Housing & Owner-Occupied & Renter-Occupied \\
\hline \multirow{3}{*}{ Northeast } & Single-Family & $83 \%$ & $5 \%$ \\
& Multi-Family & $13 \%$ & $91 \%$ \\
& Mobile Home & $4 \%$ & $5 \%$ \\
\hline \multirow{2}{*}{ Midwest } & Single-Family & $89 \%$ & $33 \%$ \\
& Multi-Family & $5 \%$ & $64 \%$ \\
& Mobile Home & $6 \%$ & $3 \%$ \\
\hline \multirow{2}{*}{ South } & Single-Family & $86 \%$ & $41 \%$ \\
& Multi-Family & $3 \%$ & $53 \%$ \\
& Mobile Home & $11 \%$ & $5 \%$ \\
\hline \multirow{2}{*}{ West } & Single-Family & $87 \%$ & $37 \%$ \\
& Multi-Family & $5 \%$ & $61 \%$ \\
& Mobile-Home & $8 \%$ & $3 \%$ \\
\hline \hline
\end{tabular}

Renters spend a much higher percentage of their typically lower income on housing costs, roughly 27\%. The Midwest has the lowest median renter-occupied household income, $\$ 18,483 /$ year, while the West has the highest median income, $\$ 23,013 /$ year. Median renter-occupied housing costs are highest in the West (\$557/month) and lowest in the Midwest (\$402/month).

Home size is an important housing characteristic. Overall, the largest owner-occupied homes are in the Northeast, with a median square footage of 2,134 . The South contains the smallest owner-occupied homes, averaging 1,602 square feet. Nationally, the median square footage of renter-occupied homes is significantly less than that of owner-occupied homes. However, rental-unit floor area follows a pattern similar to that of owner-occupied homes; the largest rental units are in the Northeast and the smallest are in the South.

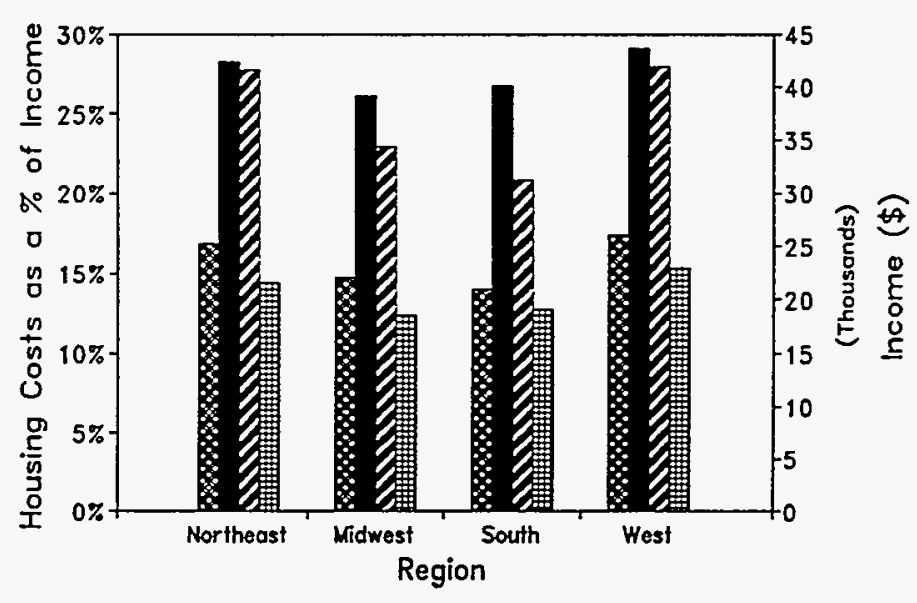

808\% \% owner $\%$ renter WOS owner $\$$ renter

Figure A.3. Housing Costs and Median Income by Region 
Figure A.4 shows that average household energy consumption and the consumption by end-use vary considerably by census region. ${ }^{(0)}$ In all regions, space heating uses the most energy. As expected from climate differences, space heating energy use is far more in the Northeast and Midwest than in the other regions. The use of appliances and hot water is relatively constant across the four areas, whereas homes in the South consume the most energy for air conditioning. Generally, space heating consumes the most energy, although not necessarily contributing the most to energy costs; appliances consume a significant amount as well.

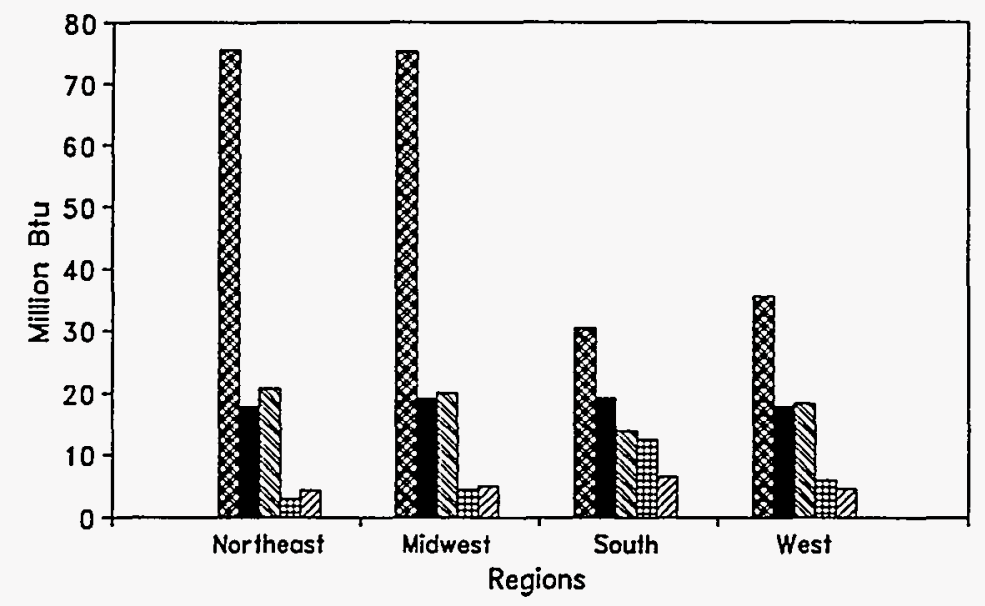

838 Spoce Heoting Hot Woter Air Conditioners QRA Regrigerators

Figure A.4. End-Use Energy Consumption Per U.S. Household by Census Region (ElA 1993b)

(a) It is important to note that the energy consumption patterns illustrated are for owner-and renteroccupied units combined. 


\section{DISTRIBUTION}

No. of

Copies

\section{OFFSITE}

2 DOE/Office of Scientific and

Technical Information

\section{ONSITE}

DOE Richland Operations Office

D. D. Green

\section{Pacific Northwest Laboratory}
A. D. Lee
Publishing Coordination
Technical Report Files (5) 